\title{
ASIP wt Allele
}

National Cancer Institute

\section{Source}

National Cancer Institute. ASIP wt Allele. NCI Thesaurus. Code C131342.

Human ASIP wild-type allele is located within 20q11.2-q12 and is approximately $75 \mathrm{~kb}$ in length. This allele, which encodes agouti-signaling protein, plays a role in the regulation of melanogenesis. Homozygous polymorphism in the 3' untranslated region of the gene is associated with an increased likelihood of having dark hair and brown eyes. 